- FINANSE I PRAWO FINANSO WE.

- Journal of Finance and Financial Law $•$

Czerwiec/June 2017 • vol. 2(14): 101-113

http://dx.doi.org/10.18778/2391-6478.2.14.08

\title{
OCHRONA PRAW KONSUMENTA W KONTEKŚCIE REALIZACJI TZW. PLANÓW SPRZEDAŻY W BANKU KOMERCYJNYM
}

\author{
Kamila Trzeciak \\ Koło Naukowe Bankowości \\ Uniwersytet Ekonomiczny w Katowicach
}

\section{Streszczenie}

Banki komercyjne nastawione na osiąganie zysków często stosują nieuczciwe praktyki rynkowe. Realizacja przez nie tzw. planów sprzedażowych powoduje często wymuszanie na klientach podpisania umów, które nie odpowiadają ich interesom. Straty, które w związku z tym ponoszą mają wpływ na to, że klienci przestają postrzegać banki jako instytucje zaufania publicznego. Banki dążą do wzrostu sprzedaży nie tylko kosztem klientów, ale także własnych pracowników. Plany sprzedaży demotywują pracowników i mają negatywny wpływ na wydajność pracy. Artykuł podkreśla problem realizacji w bankach planów sprzedażowych, które wymuszają oszukańcze i nieetyczne zachowania. Wskazuje jednak, że klienci mają wiele narzędzi walki z bankami i nie pozostają w niej osamotnieni. Oszukiwani przez banki klienci mają liczne możliwości dochodzenia swoich praw.

Słowa kluczowe: ochrona konsumentów, plan sprzedaży, misselling.

JEL Class: G21, G22. 


\section{WPROWADZENIE}

Warunkiem utrzymania pozycji rynkowej przez współczesne banki jest wygenerowanie przez nie wysokich dochodów. Srodkiem do osiągnięcia tego celu staje się zawieranie coraz większej liczby umów z klientami. Jest to nieodłączny element pracy banków i wymaga od nich prowadzenia agresywnej polityki sprzedaży oraz zaangażowania nowoczesnych narzędzi marketingu. Banki oczekują od swoich pracowników przede wszystkim wzrostu sprzedaży nawet kosztem wzrostu ryzyka klientów. W ten sposób z instytucji zaufania publicznego zamieniają się $\mathrm{w}$ supermarket $\mathrm{z}$ usługami finansowymi. Taka krótkowzroczna polityka prowadzi do nadużyć nie tylko wobec klientów, ale także własnych pracowników operacyjnych.

Przedstawiając ofertę swoich produktów, banki prowadzą akcje promocyjne często wykorzystując nieuczciwą reklamę i różne formy wywierania presji na klientach. Stosując nieetyczne zachowania, zmuszają ich do zakupu niechcianych i niepotrzebnych produktów przez podawanie informacji w sposób niejasny, zaniechanie informacji, a nawet przez celowe wprowadzanie klientów w błąd.

Celem referatu jest ocena problemu zmuszania pracowników banków do realizowania tzw. planów sprzedaży i wzrostu w związku z tym oszukańczych zachowań wobec klientów. W referacie postawiona została hipoteza, że plany sprzedaży mają charakter antymotywacyjny, demobilizują pracowników oraz negatywnie wpływają na jakość sprzedaży oraz satysfakcję klientów z korzystania z usług bankowych.

Opracowanie podzielone jest na trzy części. Pierwsza część zawiera omówienie istoty planów sprzedaży w bankach komercyjnych i metod ich wdrażania. Druga zwraca szczególną uwagę na bezpieczeństwo konsumentów banków. W ostatniej części została dokonana ocena możliwości przeciwstawienia się przez klientów nieuczciwym praktykom stosowanym przez banki komercyjne. $\mathrm{W}$ opracowaniu zastosowano analizę porównawczą, metodę stopniowej weryfikacji oraz koniunkcji.

\section{PLAN SPRZEDAŻY W STRATEGII BANKU KOMERCYJNEGO}

Bank komercyjny funkcjonuje na zasadach rynkowych, co oznacza, że jego cel stanowi dążenie do wypracowania zysku. Komercyjny oznacza działanie przynoszące dochód. Komercjalizm banku polega zatem na takim obrocie pieniądzem, by osiągnąć jak najwyższą korzyść finansową. Uniwersalny bank komercyjny zarabia na sprzedaży różnorodnych produktów i usług finansowych. Oprócz tradycyjnych produktów depozytowo-kredytowych i pośrednictwa w rozliczeniach zajmuje się także sprzedażą instrumentów rynku kapitałowego 
i ubezpieczeniowego, a w szczególności obsługą różnego rodzaju funduszy inwestycyjnych i emerytalnych, polis na życie i dożycie oraz instrumentów pochodnych [Iwanicz-Drozdowska 2005:27-28]. Poszerzenie oferty produktów o nowe instrumenty sprzyja nakłanianiu klientów do nabywania dodatkowych usług w ramach tzw. sprzedaży wiązanej. Wielokrotnie zdarza się, że dodatkowe produkty są klientom zbędne, a płacone od nich prowizje zwiększają koszt usługi podstawowej.

Te i podobne praktyki związane są z prowadzoną strategią sprzedaży, która zakłada przynajmniej utrzymanie dotychczasowej pozycji rynkowej, a najlepiej jej wzrost. Bez wzrostu sprzedaży nie jest bowiem możliwy długotrwały sukces oraz uzyskanie stabilności i długoterminowej rentowności banków. Strategia jest pojęciem stosowanym powszechnie do określenia ogólnego planu działalności banku wykorzystującego jego potencjał, by osiągnąć wyznaczone cele. Opracowanie strategii banku jest jednak procesem trudnym, gdyż w budowanej strategii należy wziąć pod uwagę wiele zróżnicowanych czynników [Pyka 2013: 74].

Strategia sprzedaży określa sposób organizacji i zadania wydziałów zajmujących się tworzeniem i realizacją oferty banków. Należą do nich w szczególności piony kredytowy, depozytowy i rozliczeń pieniężnych. Niezbędnym elementem strategii sprzedaży jest plan sprzedaży obejmujący:

- analizę dotychczasowej sytuacji banku,

- wyznaczenie celów sprzedażowych,

- wybór metod i narzędzi realizacji planu sprzedaży,

- monitorowanie realizacji planu sprzedaży [Por. Próchnicki 2014].

Analiza sytuacji banku pozwala na wytyczenie kierunku dalszego rozwoju. Pomaga ustalić słabe i mocne strony jego dotychczasowej działalności i podjąć środki służące poprawie efektywności sprzedaży, m.in. przez wyznaczenie celów sprzedaży takich, jak:

- określenie grupy klientów docelowych,

- segmentacja klientów,

- ustalenie optymalnego poziomu cen,

- wskazanie cech unikalnych produktów i ich konkurencyjności,

- identyfikacja własnej pozycji na rynku.

Efektywną sprzedaż zapewnia określenie struktury sprzedaży oraz profilu klientów. Bank powinien poznać ich potrzeby oraz stosunek do ryzyka i dochodowości produktów. Na tej podstawie bank dokonuje segmentacji klientów, co pozwala dobrać ofertę dokładnie według ich potrzeb oraz zoptymalizować kanały dystrybucji produktów i usług. Ofertę tę przedstawiają pracownicy wyszkoleni do kontaktów z klientem.

Plany sprzedaży realizują prognozy i cele sprzedażowe, które określają, co banki pragną osiągnąc $\mathrm{w}$ określonym czasie i na określonych rynkach. Pokazują szczegółowo, w jaki sposób te zamiary mają być uzyskane $\mathrm{z}$ wykorzystaniem 
personelu sprzedażowego. Elementy planu sprzedażowego stanowi wyznaczenie zadań dla sprzedawców w postaci tzw. kwot sprzedażowych oraz ustalenie logicznej kolejności działań prowadzących do realizacji kwot sprzedażowych. Struktura typowego planu sprzedaży obejmuje kwoty bazujące na: sprzedaży (ilość, wartość, punkty sprzedażowe), aktywności sprzedawców i wynikach finansowych (wydatki i wyniki) [Cybulski 2004: 46].

Do elementów planu działania akwizycyjnego zaliczyć można:

- wykaz miesięcznych i tygodniowych celów sprzedażowych,

- wykaz targetów w układzie poszczególnych dni roboczych,

- liczbę planowanych telefonicznych rozmów handlowych i konferencji,

- zestawienie planowanych wizyt i prezentacji handlowych oraz wizyt związanych z obsługą posprzedażową [Cybulski 2004: 96].

Plan działań akwizycyjnych ma za zadanie doprowadzenie do wzrostu średniej wartości sprzedaży oraz zwiększenia wartości sprzedaży, poprawienia wskaźnika liczby kontaktów do transakcji (zmniejszenie liczby kontaktów) oraz ograniczenia czasu trwania wizyty (kontaktu).

\section{MOTYWACJA PRACOWNIKÓW JAKO ELEMENT PLANU SPRZEDAŻY}

Jednym z podstawowych warunków efektywności planu sprzedaży produktów bankowych jest zatrudnienie właściwych pracowników na stanowiskach wymagających kontaktu z klientem. Ich umiejętności i zaangażowanie pozwalają na zwiększanie obrotów oraz rentowności. Odpowiedni pracownicy budują zatem siłę konkurencyjną banku. Ich rekrutacja stanowi ważny element strategii sprzedaży. W związku z tym podstawowym zadaniem banku jest ustalenie i stałe monitorowanie kompetencji i predyspozycji pracownika, a szczególności umiejętności nawiązania kontaktu z klientem, przekonania go do zakupu, sprawności obsługi, przyswajania wiedzy o nowych produktach.

Stosowane w bankach plany sprzedaży narzucają pracownikom poziom miesięcznej sprzedaży w postaci określonej liczby umów sprzedaży lub osiągnięcia przychodów o określonej wysokości. Dążenie do ich realizacji często wiąże się z wymuszaniem na pracownikach zachowań nieetycznych, np. w postaci sprzedaży produktów, których sami nie nabyliby lub nie polecili. Zdarza się wielokrotnie, że pracownicy sami nie rozumieją potrzeby posiadania przez klienta sprzedawanego produktu lub uważają, że jest on klientowi w ogóle niepotrzebny.

Żądania stawiane przez zarząd pracownikom operacyjnym są często zbyt wygórowane, stwarzając barierę ich realizacji. Nadmiar wymagań wobec pracowników wywołuje u nich najczęściej stres. Wśród czynników stresogennych wyróżnia się wielozadaniowość, pogorszenie relacji przełożony-podwładny, 
fluktuację zatrudnienia, brak identyfikacji z firmą oraz duże naciski na efekty finansowe. Zbyt duże wymagania uniemożliwiają wykonanie planu sprzedaży i zniechęcają personel do pracy. Z kolei ustalenie wartości sprzedaży na niskim poziomie demotywuje do działania, obniżając jednocześnie wydajność pracy. Przyjmuje się, że takie cele są „,niedoszacowane”, co oznacza, że cel jest łatwy do osiągnięcia i nie wykorzystuje potencjału rynku [Judek, Strategia..., dostęp: 25.03.2017].

Dążąc do maksymalizacji sprzedaży, banki z reguły traktują pracowników zaangażowanych w bezpośrednią obsługę klientów, jak zwykłych sprzedawców. W celu osiągnięcia zamierzonych wyników stosują różne formy motywacji pozytywnej oraz negatywnej. Negatywna motywacja wykorzystuje ujemne bodźce motywacyjne. Oparta jest na lęku i obawie. Pracownicy są pobudzani do pracy przez stwarzanie poczucia zagrożenia. Wywołuje się u nich lęk, że mogą stracić to, co już udało im się osiągnąć. Negatywna motywacja może więc powodować wśród pracowników obniżenie poczucia własnej wartości, spadek ambicji oraz przyjmowanie postawy defensywnej. Pracodawcy chętnie stosują motywację negatywną, ponieważ jest ona mniej kosztowna i skuteczna w zastosowaniu. Pomimo widocznych, doraźnych efektów, w dłuższej perspektywie prowadzi do demotywacji, znacząco obniżając zadowolenie z pracy. Nosi znamiona tzw. antymotywacji [Penc 2000: 140-144].

Antymotywacja oznacza błędy w motywowaniu i stosowanie kar. W kręgu kar znajdują się krytyka, obniżenie pensji i działania dyscyplinarne, które w długim okresie wywołują reakcje obronne u pracowników, takie jak ukrywanie błędów oraz przejawianie niechętnych postaw do pracy. Niska satysfakcja z pracy spowodować może nieprzyjazne zachowania pracowników. Takie zachowania sprzyjają niskiej jakości usług, buntom, czy kradzieżom, szkodząc produktywności. Powszechnym zjawiskiem staje się również absencja pracowników. Pracownicy nie przychodzą do pracy, czując się w niej niekomfortowo. Absencja jest bardzo kosztowna dla pracodawcy. Wysoką absencją charakteryzują się podmioty, w których nie wymaga się zwolnień lekarskich. Poziom absencji zależy od wartości społecznych i tradycji w zakresie traktowania swoich obowiązków pracowniczych, stąd niska absencja występuje w krajach o wysokim poczuciu społecznego obowiązku i dyscypliny (np. Szwajcaria czy Japonia). Zauważono, że wyższa absencja występuje wśród młodszych pracowników [Schultz i Schultz 2002: 308-309].

Zarządy banków stosując wygórowane wymagania wobec pracowników i narzucając im plany sprzedażowe prowadzą ich na ścieżkę „nibyskuteczności”, zapominając o etyce. Zasady premiowania uzależnione od ilości sprzedanych produktów oznaczają usytuowanie zysku banków wyżej niż potrzeb samych klientów. Współcześnie funkcjonuje bowiem przekonanie, że dobry sprzedawca potrafi sprzedać nawet niepotrzebne produkty, a klient i tak pozostanie zadowo- 
lony. Takie podejście jest całkowicie sprzeczne z wyobrażeniami klientów, którzy chcą postrzegać banki jako instytucje, w których na pierwszym miejscu jest etyka i uczciwość, a nie zysk [Celary i Polok 2013: 98-102]. Plany sprzedażowe wymuszają też współzawodnictwo między pracownikami. Rywalizacja powoduje niechęć w niesieniu pomocy kolegom i wpływa na osłabienie siły zespołu. Skutkami wspomnianego współzawodnictwa są mobbing, spadek poczucia własnej wartości, czy wypalenie zawodowe [Plany sprzedażowe..., dostęp: 24.03.2017].

Mobbing będący patologią zarządzania jest pojęciem trudnym do zdefiniowania. Oznacza działanie polegające na długotrwałym i uporczywym zastraszaniu, ośmieszaniu czy nękaniu pracowników, które narusza godność człowieka. Jest więc to wrogie, nieetyczne i powtarzające się systematycznie zachowanie wobec jednej lub kilku osób. Mobbing jest nazywany również tyranizowaniem. Może obejmować nękanie psychiczne bądź fizyczne. Takie zachowania wywołują lęki, obawy, a także mogą doprowadzić do uszczerbku zdrowia [Bechowska-Gebhardt i Stalewski 2004: 9-12]. Liczba spraw w sądach dotyczących mobbingu, molestowania i dyskryminacji stale wzrasta. W sądach pracy w połowie 2016 r. było prawie 1000 takich spraw (dla porównania w całym 2015 r. liczba spraw wyniosła 1200). Z badań wynika, że większą grupę osób wnoszących sprawy o odszkodowanie za dyskryminację stanowią mężczyźni. Z kolei kobiety częściej są autorkami pozwów o odszkodowanie za mobbing. Zdecydowana większość spraw zostaje umorzona, ponieważ strony zawierają ugodę przed wyrokiem sądu [Rzemek, Mobbing..., dostęp: 24.03.2017].

W przeciwieństwie do antymotywacji, motywacja pozytywna oparta jest na stosowaniu dodatnich bodźców motywacyjnych. Polega ona na wpływaniu na pracownika poprzez oferowanie i stwarzanie lepszych perspektyw, gdy będzie on spełniał wymogi pracodawcy. Pracownicy są wtedy w stanie podejmować ogromny wysiłek i brać na siebie dużą odpowiedzialność. Dążą do sukcesu, oczekują podziwu i aprobaty innych. Motywacja pozytywna powoduje zwiększenie aktywności pracownika oraz większe wykorzystanie jego możliwości i umiejętności. Jej skuteczność zależy jednak od tego, czy składane pracownikowi obietnice zostaną rzeczywiście spełnione.

Motywowanie pracowników może polegać na stosowaniu nagród za dobrze wykonaną pracę. Jest to tzw. motywacja zewnętrzna. Do nagród zalicza się m.in. awans, wyższe wynagrodzenie, dodatkowe świadczenia czy pochwałę. Chęć uzyskania nagrody powoduje wykonywanie powierzonych zadań i ponoszenie wysiłku. Wyróżnia się również motywację wewnętrzną, która zakłada, że samoczynnie pojawiające się bodźce skutkują określonym postępowaniem lub dążeniem w konkretnym kierunku. Motywacja wewnętrzna wynika $\mathrm{z}$ indywidualnych potrzeb każdej osoby [Armstrong 2005: 210-211]. 
Istnieje wiele metod podnoszenia motywacji. Należą do nich m.in.:

- stawianie ciekawych wyzwań rozwijających pracowników,

- ograniczenie stałej kontroli pracowników,

- stosowanie drobnych nagród (np. za zakończenie projektu),

- poznanie potrzeb pracowników i dostosowanie pracy do nich,

- zwiększenie integracji zespołu, lepsze poznanie się personelu,

- wzrost wynagrodzenia zwiększającego motywację [Nowak, 6 sposobów..., dostęp: 24.03.2017].

\section{MOŻLIWOŚCI OCHRONY KLIENTÓW WOBEC NIEUCZCIWYCH PRAKTYK BANKÓW KOMERCYJNYCH}

Banki uważane są za instytucje zaufania społecznego. Ten wyjątkowy status nadaje im konieczność podporządkowania się wielu rygorom budującym ich bezpieczeństwo. Należą do nich: regulacje prawne, normy ostrożnościowe i tzw. ujawnienia. Regulacje mają charakter obowiązujących przepisów szczebla unijnego i krajowego, które ściśle określają najważniejsze warunki oferty i sposoby postępowania banków. Normy ostrożnościowe z kolei przyjmują najczęściej postać rekomendacji wydanych przez Komisję Nadzoru Finansowego i mające charakter zaleceń. Ujawnienia stanowią natomiast uzupełnienie dla działań nadzorczych, mechanizm dyscyplinujący banki w zakresie zarządzania ryzykiem.

Oprócz norm i przepisów, zaufanie do banku buduje także uczciwość pracowników obsługujących klientów. Ci ostatni ufają, że „reguły gry” są sprawiedliwe i uczciwe. Mają więc prawo do rzetelnej i pełnej informacji o działalności banków i ich ofercie. Wierzą, że informacja podana jest w sposób jasny i zrozumiały, zgodny z zasadami kodeksu etyki bankowej. Niestety, ze względu na stosowane w bankach plany sprzedażowe coraz częstszą praktykę stanowi naruszanie praw konsumentów, co powoduje wzrost nieufności wobec banków i całego systemu bankowego.

W swoich ofertach banki zawierają często tzw. klauzule abuzywne, czyli niedozwolone. Są one niezgodne z obowiązującym prawem i celowo wprowadzają klientów w błąd. Ich konstrukcja jest niezrozumiała dla klientów, a taryfikacja pobieranych opłat budzi wątpliwości. Takie praktyki banków powoduje zachwianie pozycji banków jako instytucji zaufania publicznego. Następuje także utrata ich dobrego wizerunku, przez co banki tracą swą reputację [Celary i Polok 2013: 105-106].

Do przyczyn, które doprowadziły do nieporozumień pomiędzy klientami a bankami można zaliczyć:

- błędy pracowników,

- niedyskrecję, 
- błędne informacje dotyczące produktów,

- za wysokie opłaty transakcyjne,

- agresywną sprzedaż,

- bezwzględne ściąganie należności [Nowakowski i Famulska 2008: 25].

Nieuczciwe praktyki stosowane przez banki komercyjne określa się mianem „missellingu”, czyli tzw. złej sprzedaży. Misselling wiąże się ze sprzedażą niepotrzebnych produktów, czy usług. Pracownicy chcąc zrealizować plan sprzedaży oferują klientom produkty, które nie są dopasowane do ich potrzeb oraz przewyższają ich możliwości finansowe. Misselling jest to działanie przede wszystkim nieetyczne, ponieważ sprzedawcy często celowo wprowadzają swoich klientów w błąd lub świadomie nie informują ich o niektórych aspektach umowy, trudnych do zaakceptowania. Najczęściej to zjawisko jest zauważalne w sprzedaży produktów ubezpieczeniowych jako usług dodatkowych przy lokatach, jak i kredytach. Te produkty są mało przydatne klientom, a czasami zupełnie niepotrzebne [www 1, dostęp: 25.03.2017].

Do charakterystycznych cech missellingu zalicza się:

- sprzedaż osobom starszym produktów długoterminowych,

- brak wyjaśnień o konstrukcji produktu (często skomplikowanej) oraz jego likwidacji,

- brak informacji o ryzyku instrumentu,

- brak informacji o sposobie obliczania dochodu klienta [Wojnowska i Gniadek, Miss...co?!?..., dostęp: 25.03.2017].

Oprócz spadku zaufania do banków efektem missellingu jest także postrzeganie banków jako instytucji wykorzystujących naiwność klientów i rosnące poczucie krzywdy wśród oszukanych klientów. Wywołuje to ich ostre sprzeciwy i reakcje, a także brak chęci współpracy z przedstawicielami branż finansowych. W relacji klient - bank, klienci znajdują się z reguły na „przegranej pozycji”. Wynika to m.in. z nierównego dostępu do informacji oraz przewagi finansowej i technicznej banku jako wielkiej korporacji. Klienci nie są jednak zupełnie pozbawieni możliwości przeciwstawienia się bankom.

Współczesny rynek bankowy dostrzega omówione wyżej problemy i stara się reagować na powstające patologie. Klienci coraz częściej nie są osamotnieni w sytuacji, gdy zostaną oszukani przez bank i mają różne możliwości dochodzenia swoich praw. Możliwości ochrony klientów stwarzają zarówno zmiany regulacji prawnych, jak i powołanie instytucji wspomagających klientów w sporach $\mathrm{z}$ bankami. Do regulacji prawnych zaliczyć należy przede wszystkim tzw. ustawy antylichwiarskie [Ustawa z dnia 21 lipca 2006 r. ...; Ustawa z dnia 12 maja 2011 r. ...; Ustawa z dnia 5 sierpnia 2015 r. ...] oraz normy ostrożnościowe, a w szczególności rekomendacje KNF [Rekomendacje dla banków - Rekomendacja T...: 33-34, dostęp: 31.03.2017]. Instytucje świadczące pomoc klientom stanowią natomiast Komisja Nadzoru Finansowego, Urząd Ochrony Konkuren- 
cji i Konsumentów, Rzecznik Praw Obywatelskich, Arbitraż Bankowy przy Związku Banków Polskich, a w ostateczności sądy cywilne, które rozpatrują indywidualne i zbiorowe pozwy osób oszukanych. Wspólna walka o dobro klientów przynosi powoli rezultaty w postaci zmiany charakteru wadliwych produktów finansowych.

W pierwszej kolejności klienci mogą złożyć pisemną reklamację w obecności pracownika banku. Czas rozpatrzenia pisma wynosi $30 \mathrm{dni}$, jednak w przypadku skomplikowanej sprawy bank może poprosić o wydłużenie terminu. Przy składaniu reklamacji może pomóc Rzecznik Praw Konsumentów. Jego pomoc jest bezpłatna. Gdy prawdopodobne jest, że podpisana umowa z bankiem przysporzy problemów innym klientom, sprawę można zgłosić do Urzędu Ochrony Konkurencji i Konsumentów. Sąd UOKiK uznając, że zapis w umowie klienta $\mathrm{z}$ bankiem jest szkodliwy może go wpisać do rejestru klauzul niedozwolonych.

$\mathrm{W}$ sytuacji nieosiągnięcia porozumienia $\mathrm{z}$ bankiem klienci mogą zwrócić się do arbitra bankowego przy ZBP, lecz wartość roszczeń nie może przekraczać 8000 zł. Koszt złożenia wniosku do arbitra wynosi 50 zł (lub 20 zł, gdy wartość sporu jest mniejsza niż 50 zl). Rozpatrzenie wniosku następuje w ciągu 2 miesięcy. W przypadku przegranej bank nie ma możliwości odwołania się od tej decyzji. Musi w trakcie 14 dni oddać pieniądze. Przegrana klienta nie oznacza braku możliwości dochodzenia swoich roszczeń. Sprawę może ponownie skierować do sądu. Sąd Polubowny przy KNF zajmuje się sprawami klientów indywidualnych. Spory są rozpatrywane, gdy wartość przedmiotu sporu przekracza $500 \mathrm{zł}$. Klient ma dwie możliwości: mediację i arbitraż. Rozwiązanie sporu poprzez mediację kosztuje $250 \mathrm{zl}$, lecz jeśli dojdzie do ugody sąd zwróci klientowi $70 \%$ opłaty. Arbitraż w postępowaniu sądowym również kosztuje $250 \mathrm{zl}$, ale gdy klient przegra może zostać obciążony dodatkowymi kosztami. Wyrok sądu przy KNF ma obligujący charakter dla obu stron. Ostatecznością jest złożenie pozwu do sądu cywilnego. Sąd powołuje biegłych. Czas rozpatrywania sprawy jest znacznie dłuższy i wynosi 1-2 lata. Rozstrzygnięcie sprawy na korzyść klienta skutkuje uzyskaniem kwoty roszczenia, ale też odszkodowania (gdy klient o nie wystąpi i odpowiednio uzasadni) [Knitter, 5 sposobów..., dostęp: 24.03.2017].

W latach 2012-2015 do Bankowego Arbitrażu Konsumenckiego wpłynęło 5085 wniosków. W stosunku do 2012 r. w 2015 r. liczba wniosków wzrosła o ponad 15\%. W relacji jednak do roku 2014 liczba wniosków spadła o 7\%. W 2015 r. na korzyść zmieniła się liczba wydanych orzeczeń. Po raz pierwszy ich liczba była większa niż liczba złożonych w tym roku wniosków. Świadczy to o przyspieszeniu okresu rozpatrywania skarg, który skrócił o 9 dni w stosunku do roku poprzedniego. Blisko trzykrotnie wzrosła również liczba skarg rozpatrzonych na korzyść klientów. Nadal jednak udział wniosków rozpatrzonych na 
korzyść klientów jest niski. W okresie 2012-2014 wydano bowiem łącznie orzeczenia w 4991 sprawach, w tym na korzyść klienta rozstrzygnięto zaledwie 895 spraw. Początkowo, w okresie stanowiło to średnio 14\% wydanych orzeczeń. W 2015 r. nastąpiła wyraźna poprawa i wzrost spraw rozstrzygniętych na korzyść klienta do $26 \%$. Średni czas oczekiwania na rozpatrzenie wniosków wynosił 72 dni (tab. 1).

Tabela 1. Statystyka skarg wnoszonych do Bankowego Arbitrażu Konsumenckiego w latach 2012-2015

\begin{tabular}{|l|c|c|c|c|}
\hline Liczba & 2012 & 2013 & 2014 & 2015 \\
\hline Wniosków & 1129 & 1253 & 1402 & 1301 \\
\hline Wydanych orzeczeń & 1049 & 1164 & 1135 & 1643 \\
\hline Na korzyść klienta & 130 & 182 & 161 & 422 \\
\hline Ugoda & 56 & 53 & 38 & 43 \\
\hline Na korzyść banku & 317 & 366 & 372 & 687 \\
\hline $\begin{array}{l}\text { Wniosków zwróconych lub } \\
\text { odrzuconych }\end{array}$ & 542 & 563 & 564 & 487 \\
\hline Czas oczekiwania w dniach & 59 & 56 & 91 & 82 \\
\hline
\end{tabular}

Źródło: opracowanie własne na podstawie: Sprawozdań z działalności Bankowego Arbitrażu Konsumenckiego za lata 2012-2015...: 2-3, [dostęp: 23.03.2017].

Udział wydanych orzeczeń na korzyść klienta w całości jest zbyt niski. Związek Banków Polskich broni bowiem interesów banków do końca, nawet gdy Trybunał Konstytucyjny orzeka, że wykorzystywany przez nie instrument faworyzował jedną stronę umów kredytowych. ZBP jako podmiot utrzymywany ze składek banków komercyjnych broni ich interesu za wszelką cenę i niechętnie orzeka na niekorzyść banków.

Z raportów ZBP wynika, że najwięcej wniosków dotyczyło umów kredytowych (wykres 1). Przyczynami sporów było występowanie klauzul niedozwolonych, niejasne zasady w umowach, zasady ustanawiania zabezpieczeń, żądanie przez bank dodatkowego zabezpieczenia spłaty kredytu. W 2015 r. pojawiły się pierwsze skargi dotyczące nieautoryzowanych operacji dokonywanych za pośrednictwem bankowości elektronicznej. Na podobnym poziomie do lat ubiegłych kształtuje się liczba wniosków związanych z transakcjami oszukańczymi dokonywanymi za pomocą kart płatniczych oraz liczba kwestionowanych przez klientów transakcji bankomatowych. Spadła natomiast liczba skarg dotyczących polisolokat [www 2]. 


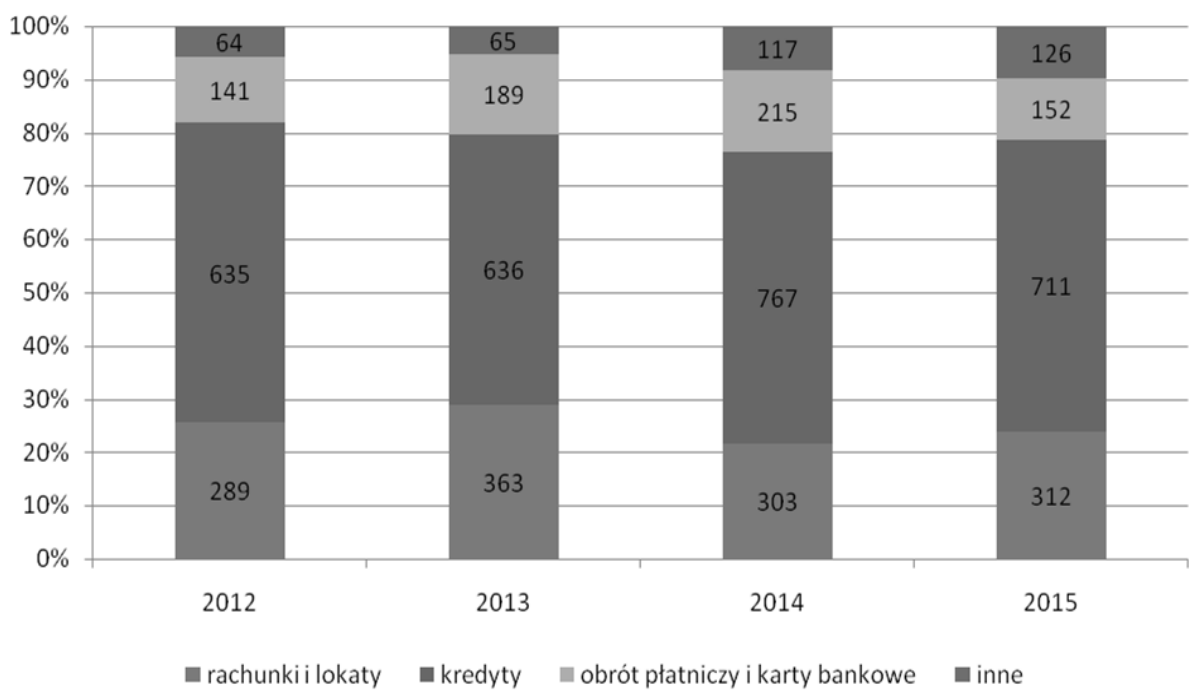

Wykres 1. Zakres merytoryczny wniosków składanych do Bankowego Arbitrażu Konsumenckiego w latach 2012-2015

Źródło: opracowanie własne na podstawie: Sprawozdań z działalności Bankowego Arbitrażu Konsumenckiego za lata 2012-2015...: 2-3, [dostęp: 23.03.2017].

Jednym ze sposobów przeciwdziałania nieuczciwym praktykom rynkowym jest zwiększenie uprawnień Urzędu Ochrony Konkurencji i Konsumentów polegające na wprowadzeniu możliwości wydawania tzw. decyzji tymczasowych. Dzięki temu UOKiK może w szybki sposób reagować na praktyki zagrażające konsumentom. Powinno to skłonić banki do dostosowania oferowanych przez nie produktów do potrzeb klientów i przyczynić się do wzrostu poziomu społecznego zaufania do banków [Kisiel, Najważniejsze..., dostęp: 24.03.2017].

\section{PODSUMOWANIE}

Banki pełniąc rolę pośredników finansowych, prowadzą działalność opierającą się na powierzonych im środkach. Podstawową dewizą, jaką powinny się kierować jest w związku z tym odpowiedzialność wyrażająca gotowość do ponoszenia skutków własnego działania. Specyficzny charakter działalności bankowej łączący cele komercyjne ze służebnością wobec klientów, zmuszają je do prowadzenia szczególnej strategii sprzedaży. Konflikt między interesariuszami, czyli z jednej strony akcjonariuszami dążącymi do maksymalizacji zysków i klientami oczekującymi, aby bank był społecznie użyteczny, wymusza dużą 
dbałość w zakresie budowania oferty i form obsługi. Dlatego pożądane jest znalezienie równowagi między dochodowością banku, a odpowiedzialnością za bezpieczeństwo klientów.

Banki posiadają uprzywilejowaną pozycję na rynku w porównaniu do klientów. Mają większe możliwości egzekwowania swoich praw. Dlatego niejednokrotnie uciekają się do stosowania nieuczciwych metod sprzedaży, nie obawiając się konsekwencji. Stosują nieuczciwą reklamę oraz zachowania sprzeczne z dobrymi obyczajami obsługi, a w szczególności do fałszywej informacji. Powinny jednak pamiętać, że zaufanie nie jest dane raz na zawsze. Jego budowa jest działaniem mozolnym i długookresowym, podczas gdy utrata przebiega zazwyczaj szybko i trudno je zbudować na nowo. Licencjonowany charakter banków, podleganie systemowi kontroli publicznej oraz gwarancje dotyczące odzyskania środków powierzonych bankom wpływają dodatnio na bezpieczeństwo.

Stosowane obecnie plany sprzedażowe mają negatywny wpływ nie tylko na klientów bezpośrednio odczuwających ich skutki, ale także na pracowników, którzy działają w stresie, pod presją, że niezrealizowane plany z kilku miesięcy spowodują zmniejszenie wynagrodzenia bądź nawet utratę zatrudnienia.

\section{BIBLIOGRAFIA}

Armstrong M., 2005, Zarządzanie zasobami ludzkimi, Oficyna Ekonomiczna, Kraków.

Bechowska-Gebhardt A., Stalewski T., 2004, Mobbing - patologia zarzadzania personelem, Difin, Warszawa.

Celary I., Polok G. (red.), 2013, Odpowiedzialność w przestrzeni społeczno pastoralnej, Wydawnictwo Uniwersytetu Ekonomicznego w Katowicach, Katowice.

Cybulski K., 2004, Zarzadzanie dziatem sprzedaży firmy, Wydawnictwo Naukowe PWN, Warszawa.

Iwanicz-Drozdowska M., 2005, Zarządzanie finansowe bankiem; Polskie Wydawnictwo Ekonomiczne, Warszawa.

Judek R., Strategia sprzedaży na 2016 r. w 5 prostych krokach, https://bonaverba.com.pl/strategiasprzedazy-2016.

Kisiel M., Najważniejsze zmiany dla klientów banków w 2016 r., http://www.bankier.pl/wiado mosc/Najwazniejsze-zmiany-dla-klientow-bankow-w-2016-roku-7291523.html.

Knitter M., 5 sposobów na walkę z bankiem o swoje prawa, http://www.money.pl/banki/wiado mosci/artykul/piec;sposobow;na;walke;z;bankiem;o;swoje;prawa,157,0,687005.html.

Nowak A., 6 sposobów podnoszenia motywacji pracowników, http://di.com.pl/6-metod-podnosze nia-motywacji-pracownikow-50366.

Nowakowski J., Famulska T., 2008, Stabilność i bezpieczeństwo systemu bankowego, Difin, Warszawa.

Penc J., 2000, Motywowanie w zarządzaniu, Wydawnictwo Profesjonalnej Szkoły Biznesu, Kraków.

Plany sprzedażowe jako podstawowa determinanta tamania etyki $w$ sektorze bankowości i finansów, https://zbp.pl/public/repozytorium/dla_bankow/prawo/konkurs/etyka.w.finansach.praca. marcin.stronski.pdf. 
Próchnicki W., 2014, Budowanie strategii sprzedaży wspierającej wykonanie założonego planu sprzedażowego, ,Szef Sprzedaży”, nr 17.

Pyka I. (red.), 2013, Bankowość komercyjna, Wydawnictwo Uniwersytetu Ekonomicznego w Katowicach, Katowice.

Rekomendacje dla banków, Rekomendacja $T$ dotyczaca dobrych praktyk $w$ zakresie zarządzania ryzykiem detalicznych ekspozycji rynkowych, https://www.knf.gov.pl/regulacje/praktyka/rekomendacje_banki/rekomendacje.html.

Rzemek M., Mobbing i nierówne traktowanie - przybywa spraw sądowych przeciwko pracodawcom, http://www.rp.pl/Kadry/308179985-Mobbing-i--nierowne-traktowanie---przybywa-sprawspraw-sadowych-przeciwko-pracodawcom.html\#ap-2.

Schultz D. P., Schultz S. E., 2002, Psychologia a wyzwania dzisiejszej pracy, Wydawnictwo PWN, Warszawa.

Sprawozdania z działalności Bankowego Arbitrażu Konsumenckiego za lata 2012-2015, Warszawa 2013-2016, https://zbp.pl/dla-konsumentow/arbiter-bankowy/sprawozdania.

Ustawa z dnia 12 maja 2011 r. o kredycie konsumenckim, Dz.U. 2016, poz. 1528.

Ustawa z dnia 21 lipca 2006 r. o nadzorze finansowym, Dz.U. 2016, poz. 174, 615, 888, 996, 1823.

Ustawa z dnia 5 sierpnia 2015 r. o zmianie ustawy o ochronie konkurencji i konsumentów oraz niektórych innych ustaw, Dz.U. 2015, poz. 1634.

Wojnowska S., Gniadek K, Miss...co?!?, „Gazeta Ubezpieczeniowa”, http://www.gu.com.pl/ index.php?option=com_content\&view=article\&id=56955: $\mathrm{miss}-$ co\&catid=122\&Itemid=153.

[www 1] http://www.investorwords.com/18753/misselling.html\#ixzz4FbZqYNdo,

[www 2] www.zbp.pl/public/repozytorium/dla_konsumentow/arbiter_bankowy/sprawozdania/spra wozdanie_z_dzialalnosci_Bankowego_Arbitrau_Konsumenckiego_w_2015_roku.pdf.

\title{
PROTECTION OF CONSUMER RIGHTS IN THE CONTEXT OF REALIZATION SO-CALLED SALES PLANS IN A COMMERCIAL BANK
}

\begin{abstract}
Commercial banks which are focused on increase of profits, frequently use dishonest market practices. Sales plan realizaton frequently causes force on customers sign the contracts, which are not good for customer's interests. Losses which they incure have impact for that customers stop thinking that the banks are institution of public trust. Banks seek to increase sales not only cost customers, but also their workers. Sales plans are demoting for workers and have negative impact for work efficiency. The article emphasize the problem of realization sales plans in banks which force deceptive and unethical behaviors. However customers have many tools fight with banks and they are not alone. Deceived customers by banks have a lot of possibility claim their rights.
\end{abstract}

Keywords: consumers protection, sales plan, misspelling. 